\title{
Review
}

\section{Overview and Current Status of Alzheimer's Disease in Bangladesh}

\author{
Md. Rashidur Rahman*, Afsana Tajmim, Mohammad Ali and Mostakim Sharif \\ Department of Pharmacy, Jessore University of Science and Technology, Jessore, Bangladesh
}

Accepted 16 May 2017

\begin{abstract}
Alzheimer's disease (AD) is a complex neurological disorder with economic, social, and medical burdens which is acknowledged as leading cause of dementia marked by the accumulation and aggregation of amyloid- $\beta$ peptide and phosphorylated tau (p-tau) protein and concomitant dementia, neuron loss and brain atrophy. AD is the most prevalent neurodegenerative brain disorder with sporadic etiology, except for a small fraction of cases with familial inheritance where familial forms of AD are correlated to mutations in three functionally related genes: the amyloid- $\beta$ protein precursor and presenilins 1 and 2, two key $\gamma$-secretase components. The common clinical features of AD are memory impairment that interrupts daily life, difficulty in accomplishing usual tasks, confusion with time or place, trouble understanding visual images and spatial relationships. Age is the most significant risk factor for AD, whereas other risk factors correlated with $\mathrm{AD}$ are hypercholesterolemia, hypertension, atherosclerosis, coronary heart disease, smoking, obesity, and diabetes. Despite decades of research, there is no satisfying therapy which will terminate the advancement of AD by acting on the origin of the disease process, whereas currently available therapeutics only provide symptomatic relief but fail to attain a definite cure and prevention. This review also represents the current status of AD in Bangladesh.
\end{abstract}

Keywords: Alzheimer's disease, age, risk factors, diagnosis, genes

\section{INTRODUCTION}

Alzheimer's disease (AD) is a multifactorial neurodegenerative brain disorder in which approximately 5.3 million people in the United States, including almost half of the population at 85 years and older have affected and it has become a devastating condition with a huge societal impact, both in terms of financial cost and the progression of number of older people [1,2]. It has become the only one of the top ten causes-of-death with unknown genetic causes as well as no specified diagnosis and diseasealtering treatments [3]. Neuritic plaques containing amyloid- $\beta$ peptide $\left(\mathrm{A} \beta_{42}\right)$ and neurofibrillary tangles

\footnotetext{
*Correspondence to: Md. Rashidur Rahman, Assistant Professor, Department of Pharmacy, Jessore University of Science and Technology, Jessore-7408, Bangladesh. Tel.: +880 1727510926; E-mail: mr.rahman@ just.edu.bd.
}

composed of hyperphosphorylated tau are considered as microscopic hallmarks of $\mathrm{AD}$ [4]. AD results from a combination of genetic, environmental and lifestyle factors [5]. Although, at present there is no permanent known cure of $\mathrm{AD}$, current treatment advances are designed for assisting people to maintain mental function, manage behavioral symptoms, and slow or delay the symptoms of disease by targeting specific genetic, molecular, and cellular mechanisms so that the actual underlying cause of the disease can be prevented [1]. The clinical presentation of AD is heterogeneous and insidious, whereas the psychological and financial effects of AD on caregivers and family members are significant. In this review, we study clinical features of $\mathrm{AD}$, various risk factors; several genes associated with $\mathrm{AD}$, available diagnosis process, pathophysiology of $\mathrm{AD}$, treatment of $\mathrm{AD}$. We also emphasize on the recent advances on the 
molecular pathogenesis and the implications for the development of treatment and of new methods for early diagnosis, taking into account existing observations.

\section{CLINICAL FEATURE}

$\mathrm{AD}$ is an irreversible, progressive brain disorder which slowly demolishes memory and thinking skills and, eventually, the power of accomplishing the simplest tasks [1]. Being a neurodegenerative disease [6], AD slowly and progressively declines brain cells. As it is the most common form of dementia, it affects 60-65\% percent of people with dementia worldwide [7-9]. It is named after German neurologist Alö̈ Alzheimer, who in 1907 first recognized the symptoms as well as the neuropathological characteristics of the disease, such as amyloid plaques as well as tangles in the brain [6]. AD declines memory and cognitive function resulting confusion, alteration of mood and disorientation in time and space. In most people with $\mathrm{AD}$, symptoms first come along in their mid-60s [8-10] though it is neither infectious nor contagious. Again, AD can be either sporadic or familial [8] where sporadic AD can affect adults at any age usually showing effects after age 65 and is well-known as the most common form of AD [8-13]. The reason of occurring very uncommon form of $\mathrm{AD}$ named familial $\mathrm{AD}$ is mutation in one of several genes $[7,14,15]$.

Dementia is a syndrome which is characterized as the progressive deterioration of cortical functioning including language, judgment, comprehension, memory, thinking and learning [16-18]. The course of dementia will differ from person to person and is associated with a range of factors including the subtype of dementia, physical health, lifestyle factors and the social supports of the person with the disease [8]. When AD progresses, the person's ability to accomplish roles of daily living such as shopping or managing finances will be hampered, which suggests the need of personal assistance to undertake even simple activities for that person. The Diagnostic and Statistical Manual of Mental Disorders (DSM-IV) criteria for $\mathrm{AD}$ require the presence of progressive deficits in at least two cognitive domains, one of which should be memory, which are not related to any other disease process [10]. The cognitive deficits must represent a change from a previous state of normal functioning. These changes must be distinguished from acute or subacute confusional states or delirium (emetabolic encephalopathy). The recent National Institute on Aging/Alzheimer's Association criteria for dementia requires impairments in two cognitive domains for the diagnosis of dementia, not necessarily in memory functions $[8,11,12]$. The clinical features of $\mathrm{AD}$ differ among individuals where the most common initial feature is demonstrated as significant deterioration to recollect new information. This memory impairment occurs because the first neurons to malfunction and die are usually neurons in brain regions engaged in generating new memories $[8,13,15,16]$. As neurons in other parts of the brain malfunction and die, individuals experience other difficulties.

Overall, the common clinical features of $\mathrm{AD}$ are memory impairment that interrupts daily life, challenges in designing or resolving problems, difficulty in accomplishing usual tasks at home, at work or at leisure, confusion with time or place, trouble understanding visual images and spatial relationships, new problems with words in speaking or writing [8].

\section{RISK FACTOR}

Age

Age is the most significant risk factor for $\mathrm{AD}$ where the incidence of $\mathrm{AD}$ in men and women increases robustly with age [19, 20]. The International Alzheimer's Disease Report estimates that 47 million people worldwide are living with $\mathrm{AD}$ in 2015 , and this is estimated to increase to 131 million people by 2050 [21]. After the age of 65, the lifetime risk of AD is one in six for women (16.7\%), whereas it is one in eleven for men $(9.1 \%)$ [22].

\section{Obesity/metabolic syndrome}

Relationship between AD and obesity suggests an up to $40 \%$ increased risk for obese individuals in some studies, [23-26] others have observed no correlation [27-29]. Weight loss and low body mass index are significantly correlated with elevated risk of AD in older adults, whereas a higher body mass index may be protective at advanced ages [23, 30-32].

\section{Family history of Alzheimer's disease}

Family history of AD may play crucial role in the occurrence and advancement of AD. The persons whose parents or siblings are the patients of $\mathrm{AD}$ are 
more susceptible to $\mathrm{AD}$ than a person do not have family history of $\mathrm{AD}$ [33-35]. The exact relationship between the elevated risk of AD and family history of AD is not fully recognized through existing research.

\section{Smoking}

Early onset of $\mathrm{AD}$ is correlated with smoking which is considered as a modifiable risk factor for $\mathrm{AD}$ estimating to account for 4.7 million $\mathrm{AD}$ cases worldwide. Numerous studies have observed that smoking has been associated with both increased and decreased risk for AD. But, smoking during lifetime is linked with at least a 1.7 times $(70 \%)$ greater risk for $\mathrm{AD}$, and the risk markedly elevates with greater cumulative smoking exposure [36].

\section{General anesthesia and $A D$}

Several studies have reported the preclinical manifestation for the possible role of general anesthesia in the advancement of AD processes in cell culture or animal models. Current demonstration suggests the correlation between exposure to volatile general anesthesia and $\mathrm{AD}$ pathogenesis in transgenic mouse models [37, 38], whereas the evolution of tauopathy [37] and $\mathrm{A} \beta$ processes linked with $\mathrm{AD}$ have also been detected in animals exposed to general anesthesia [37].

\section{Diet}

Numerous research studies have been demonstrated that dietary components may play crucial role in the progression of AD risk observing in both human and animal models. Cognitive impairment in humans, elevated levels of $A \beta$ and tau pathology in rodents which are the predictors of AD pathogenesis are correlated with the high sucrose and fructose contents of Western diets [39-42] whereas trans and saturated fatty acids are linked with higher risk of AD and mild cognitive impairment [43, 44]. Trans and saturated fatty acids are shown to exhibit high levels of $A \beta$ by another rodent experiment $[45,46]$. Again, diet with induced oleic acid and reduced fat was found to decrease $A \beta$ levels and pathology in transgenic mice [47]. Various observations have been suggested that $A \beta$ levels decreases significantly with diets containing high omega 3 polyunsaturated fatty acids [48-51].

\section{Others}

Cardiovascular disease, social and cognitive engagement, traumatic brain injury, down syndrome etc. are also suspected as risk factors of $\mathrm{AD}$ but no significant research has been established to demonstrate their relationship with $\mathrm{AD}$ [52-64].

\section{GENETIC FACTOR}

\section{Apolipoprotein E (APOE)}

Apolipoprotein E (APOE) is one of the strongest heritable risk factor for late onset of $\mathrm{AD}$ which is located on the proximal long arm of 19th chromosome i.e., at chromosome $19 \mathrm{q} 13.2$ which encodes a pleiotropic glycoprotein [8-10, 65-67]. It is well-known essential brain apolipoprotein which is secreted by astrocytes [68-71]. In 1991, the relationship between APOE and AD was first introduced [65] and later it was affirmed in 1993 through studies of an association between the APOE $\varepsilon 4$ allele and AD risk $[6,7,66,72]$. Being distributed in liver, brain, and macrophages $[11,73]$, the APOE gene exists as three polymorphic alleles $(\varepsilon 2, \varepsilon 3$, and $\varepsilon 4)$, where the APOE $\varepsilon 3$ allele is the most common (77\%), $\varepsilon 2$ allele is the least common $(8 \%)[74,75]$. Individuals having the $\varepsilon 4$ allele have higher risk of $\mathrm{AD}$ in comparison with subjects carrying the more common $\varepsilon 3$ allele, whereas the $\varepsilon 2$ allele decreases risk [76, 77]. APOE $\varepsilon 4$ elevates risk in familial and sporadic early and lateonset $\mathrm{AD}[18]$ with dose-dependent effect on age at onset [66, 78].

\section{$A \beta P P$}

Amyloid- $\beta$ protein precursor (A $\beta P P)$ is a type- 1 transmembrane neuronal protein which is situated at chromosome 21q21 [79-82]. It acts like a signaltransduction receptor and is distributed in many tissues and intensified in the synapses of neurons [83, 84]. Firstly, A $\beta P P$ is made in the endoplasmic reticulum, then post transcriptionally modulation occurs in the Golgi (N- and O-linked glycosylation, sulfation, and phosphorylation), and finally, released to the cell surface via the secretory pathway and endocytosed and processed in the endosomal-lysosomal pathway from the cell surface $[85,86]$. Approximately $14 \%$ of early-onset autosomal dominant cases of $\mathrm{AD}$ are occurred by dominant mutations in $\mathrm{A} \beta \mathrm{PP}$, whereas 
two recessive A $\beta P P$ mutations (A673V and E693D) generate early-onset $\mathrm{AD}$ [78].

\section{Presenilin 1 (PSEN1) and Presenilin 2 (PSEN2)}

Presenilins are major components of the atypical aspartyl protease complexes which are involved in the $\gamma$-secretase cleavage of A $\beta P P$ [87]. PSEN1 and PSEN2 belong to integral membrane proteins which is composed of nine transmembrane domains with a hydrophilic intracellular loop region and located on chromosome 14q24.3 and on chromosome 1q31q42 respectively [79, 88]. It is distributed in the cell surface, Golgi, endoplasmic reticulum, and mitochondria $[89,90]$.

\section{ATP Binding Cassette Transporter 7 (ABCA7)}

Being a member of $\mathrm{ABC}$ transporter superfamily, ABCA7 was first reported in macrophages whose location of ABCA7 is on chromosome 19p13.3. It exhibits significant roles in lipid metabolism and the phagocytosis of apoptotic cells [91-93]. Through the C1q complement pathway, ABCA7 has suspected function to modulate phagocytosis of apoptotic cells by macrophages [94]. Again, it manifests in the efflux of lipids from cells into lipoprotein particles with stimulating cholesterol efflux by inhibiting $\mathrm{A} \beta$ secretion in vitro [95].

\section{AKAP9: a kinase (PRKA) anchor protein 9}

Being expressed in the hippocampus, cerebellum and the cerebral cortex and encoding with a scaffold protein with physical attachment of type I protein phosphatase and cAMP-dependent protein kinase to the N-methyl-D-aspartate receptors for stimulating channel activity, AKAP9 is located on chromosome 7q21.2 [96, 97].

\section{Bridging Integrator 1 (BIN1)}

The location of BIN1 (Bridge Integrator 1 or Amphiphysin 2) is on chromosome 2 (2q14.3) which was recognized as Myc box-dependent-interacting protein 1 by interacting with Myc-box region of the MYC oncoprotein encodes several splice variants [98-100]. The SNPs in BIN1 modulating risk for late onset $\mathrm{AD}$ were identified by genomewide association study [101, 102], whereas in aging mice, in transgenic mouse models of $\mathrm{AD}$, and in persons with schizophrenia, the variation of the nature of BIN1 has been demonstrated [103, 104]. The role of BIN1 is in enhancing Clathrin-mediated endocytosis, intracellular endosome trafficking, senescence, immune response, calcium homeostasis, and caspase-independent apoptosis [105-108], whereas BIN1 has been observed to involve in phagocytosis by macrophages and attaches $\alpha$-integrins to modulate the immune response [109].

\section{CD2 Associated Protein (CD2AP)}

The composition of scaffolding protein named CD2AP is 639 amino acids with molecular mass of approximately $70 \mathrm{kDa}$ [110] which exhibit its activities in cytoskeletal reorganization and intracellular trafficking [111]. Being distributed in adult and fetal human tissues as an approximately $5.4 \mathrm{~kb}$ transcript [112], it is located on chromosome $6 \mathrm{p} 12$ which encodes CD2 associated protein [112]. CD2AP is related in mediating vesicular trafficking to the lysosome and it is attached with proteins involved in cytoskeletal organization [113] resulting endocytosis $[114,115]$ and cell-cell interactions [116]. Ligand binding of CD2AP improves protein segregation, CD2 clustering, and cytoskeletal polarization [111].

\section{Clusterin (CLU)}

A stress-activated chaperone protein encoding three alternative transcripts named Clusterin (CLU) is a $75 \mathrm{kDa}$ apolipoprotein which is located on chromosome 8p21.1 [117, 118]. Being distributed throughout the body, especially in the brain for exhibiting its activities in apoptosis, complement regulation, lipid transport, membrane protection, and cell-cell interactions [117], clusterin alters $A \beta$ clearance, amyloid deposition, and neuritic toxicity and purified clusterin interacts with $A \beta$ affecting fibril formation in vitro $[119,120]$. By modulating the membrane attack complex, clusterin inhibits the inflammatory response associated with complement activation [117].

\section{CD33}

CD33 may mediate $A \beta$ clearance and other neuroinflammatory pathways which are controlled by microglia in the brain whereas high CD33 brain expression has been associated with AD status [121]. 


\section{Ephrin Type-A Receptor 1 (EPHA1)}

In transgenic mouse models of $\mathrm{AD}$, it was demonstrated that ephrin receptors were minimized in the hippocampus prior to the development of impaired object recognition and spatial memory, while low levels of Eph receptor have been recognized in postmortem hippocampal tissue from patients with incipient $\mathrm{AD}$ [122].

\section{SORL1}

Being originally recognized as an AD risk gene in candidate-based approaches [123, 124], SORL1 mediates the processing of A $\beta P P$ by presenilins and the production of $\mathrm{A} \beta$ [125]. Recent meta-analysis of one observation has been demonstrated a significant association between clusters of polymorphisms in SORL1 and AD in both Caucasians and Asians [126].

\section{TREM2}

One type of transmembrane receptor protein called TREM2 is located on chromosome 6q21.1 which is expressed on myeloid cells to regulate phagocytosis and suppress inflammation reactivity [127] including microglia, monocyte-derived dendritic cells, osteoclasts, and bone-marrow-derived macrophages [128].

\section{Tau}

Tau is a cardinal constituent of neurofibrillary tangles which is located on chromosome 17 of the human genome expressing six isoforms of the tau protein in adult human brain $[129,130]$. Tau has been found to be associated with induced oxidative stress, impaired protein-folding function in the endoplasmic reticulum, and deficient proteasome-mediated which is also linked with autophage-mediated clearance of damaged proteins in $\mathrm{AD}[131,132]$.

\section{Phosphatidylinositol Binding Clathrin Assembly Protein (PICALM)}

The location of the PICALM gene is on chromosome 11 (11q14.2) which is distributed in acute myeloid leukemia, acute lymphoblastic leukemia, and malignant lymphoma [133], whereas the levels of PICALM were modulated in the brain of an amyloid mouse model of AD in contrast to wild-type mice [134].

\section{DIAGNOSIS}

The diagnosis of $\mathrm{AD}$ depends on clinical features, medical history, family discussions and contemporary diagnostic tests including clinical, neurological, and psychiatric examination whereas neuropsychological testing can be recognized as a tool for getting objective signs of memory disturbances in early stages and laboratory studies, such as thyroidfunction tests and serum vitamin B12, are used to explain the secondary causes of AD. But, the 2011 criteria and guidelines recommend biomarker tests for the recognition of two biomarker categories: (1) bio-markers demonstrating the level of $A \beta$ accumulation in the brain and (2) biomarkers exhibiting that neurons in the brain are declined or actually degenerating. The proper application of theses biomarkers helps researchers to enroll individuals with the brain changes for providing treatments target $[135,136]$. Various stage of the disease with various factors, like environmental factor, genetic factors, age, sex, etc., should be considered carefully to get significant results from biomarker test or combination of test [58]. For the diagnosis of $\mathrm{AD}$, the elevated levels of cerebrospinal fluid (CSF) biomarkers have been detected in the combination magnetic resonance imaging (MRI) and CSF biomarkers as the diagnostic accuracy. All these are measured significantly through MRI to predict future clinical decline [135-138]. Again, these are demonstrated significantly by a multimodal classifier which firstly chooses MRI and fluorodeoxyglucose positron emission tomography (PET) regions of interest, then combines them with CSF biomarker data accurately [139]. Some methods used as diagnostic tools for the disease are MRI measurements of medial temporal lobe atrophy, PET imaging of glucose metabolism and $\mathrm{A} \beta$ deposits, and CSF biomarkers, but recently none of these are recommended in any consensus guidelines for diagnosis of the disease $[139,140]$. To get validated diagnosis techniques, further research is needed in large prospective studies.

\section{PATHOPHYSIOLOGY OF ALZHEIMER'S DISEASE}

The pathophysiology of $\mathrm{AD}$ is depended on numerous hypotheses because of its multifactorial characteristics [141]. Various causative factors make the pathophysiology of AD more complex involving a number of processes. Numerous hypotheses 
are associated with $\mathrm{AD}$ pathophysiology including cholinergic hypothesis, $A \beta$ hypothesis, tau hypothesis and inflammation hypothesis [142, 143]. Two major hypotheses are correlated with AD: accumulation of protein plaques which is consisted of $A \beta$ [144] as well as, the generation of neurofibrillary tangles linked to hyperphosphorylation of tau proteins [145]. These protein abnormalities and oxidative stress and inflammation, failure of synaptic function, depletion of neurotransmitters and eventual cell death [145] are associated with the pathophysiology of AD. Recently it has been recognized that the most commonly employed $A \beta$ hypotheses which is considered as triumph for the last two decades, does not account for the complicated pathophysiology of this crippling disorder [146]. The function of $A \beta$ oligomers in synaptic impairment has been reported significantly in current observations which indicates that these are primarily the only one among several other signals declining the integrity of brain functions [143, 147, 148]. Again, the generation of amyloid plaques arising in the later age which becomes prominent to be rather late event [149].

\section{TREATMENT}

\section{Anti-amyloid therapies}

Acting on $\mathrm{A} \beta$ aggregates which are well-known as amyloid plaques is the main focus of anti-amyloid therapies for the treatment of AD.

\section{Drugs to reduce A $\beta$ production}

$\beta$-secretase inhibitors: The outcome of BACE inhibitor is in significant reduced levels of $A \beta_{40}$ and $A \beta_{42}$ in brain of $A \beta P P$ transgenic mice and elevated levels of soluble $A \beta P P \beta$, soluble $A \beta P P \alpha$ secretion whereas $\beta$-secretase inhibitors betterment in cognition can be attained which in future may worsen with the advancing age [150-152].

$\gamma$ secretase inhibitors: Semagacestat (LY-450139), MK-0752, E-2012BMS-708163, PF-3084014, Begacestat (GSI-953), and NIC5-15 are found in various clinical trials to provide $\gamma$-secretase inhibiting activity, whereas Semagacestat has been observed to minimize $A \beta$ concentrations in plasma and $A \beta$ production in the central nervous system [153-155]. Ibuprofen, Indomethacin, and Sulindac sulfide which are popular subsets of non-steroidal anti-inflammatory drugs firstly attach to A $\beta P P$, then reduce $A \beta_{1-40}$ and $A \beta_{1-42}$ production with increased generation of $A \beta_{1-38}$ fragments for exhibiting their activity as $\gamma$-secretase modulators [156].

$\alpha$-secretase modulators: Agonists of muscarinic, glutamate, statins, serotonin, oestrogens, and testosterone and protein kinase $\mathrm{C}$ activators are popular $\alpha$-secretase modulator but their application in the treatment of AD is not well-understood [157].

\section{Drugs interfering with $A \beta$ aggregation}

Stemazole, curcumin, SK-PC-B70M, T-817 MA etc. have been demonstrated to provide possess therapeutic potential for the treatment of AD [158-162].

\section{Metal chelators}

In the pathogenesis of $\mathrm{AD}$, metals have been assumed to act as key-regulator in the treatment of $\mathrm{AD}$, among them that $\mathrm{Zn} / \mathrm{Cu}$-selective chelators significantly elevate the solubilization of $\mathrm{A} \beta$ deposits in AD brains. [163-165].

\section{Enzyme mediated $A \beta$ degradation}

Neprilysin, insulin degrading enzyme, plasmin, endothelin converting enzyme 1 and 2, and angiotensin-converting enzyme, etc. have been shown to possess their abilities of degrading $A \beta$ peptide [166].

\section{Therapeutic clearance of $A \beta$}

\section{Immunotherapy-mediated A $\beta$ clearance}

Immunotherapy mediated $A \beta$ clearance can be attained through active and passive immunization [167], whereas active and passive $A \beta$ immunotherapy in $\mathrm{AD} \mathrm{Tg}$ mice has been observed to minimize cerebral $A \beta$ by ameliorating cognition [168]. Active immunization with anti-A $\beta$ has been shown to elevate amyloid plaque clearance reducing plaque-associated pathology, CSF tau level and slowing patient's cognitive decline [169-172]. Again, withdrawal of amyloid plaques and elevation of behavioral performance in $\mathrm{AD}$ mice can be accomplished by its vaccination with HSV amplicons showing A $\beta$ and interleukin-4 expression [173].

\section{Targeting tau phosphorylation}

Targeting hyperphosphorylated tau is an attractive approach because various phospho-tau epitopes are selectively and specifically correlated with AD pathology. Tau phosphorylation has gained importance in $\mathrm{AD}$ leading to microtubule instability. 
Inhibition of glycogen synthase kinase 3 (GSK3) and cyclin dependent kinase 5 (CDK5), primary enzymes affecting tau phosphorylation enzymes may prevent tau phosphorylation. Both lithium and roscovitine have been reported to inhibit the actions on these kinases, whereas both lithium and valproate which are active against GSK3 $\beta$ can diminish tau pathology in transgenic mice [174-177]. Recently, an irreversible inhibitor of GSK3 $\beta$ called Tideglusib (NP031112) and other small molecule inhibitors of GSK3 like SB216763, SRN-003-556 [178] and CHIR-98014 [179] are being studied to observe their supposed prominent role in the treatment of AD.

\section{Herbal supplements}

Herbal supplements which can be used in the treatment of AD are Panax ginseng, Ginkgo biloba (EGb761), Withania somnifera, Curcuma longa [180-188].

\section{Other miscellaneous therapies}

\section{Statins}

Treatment with 3-hydroxy-3-methylglutarylcoenzyme A reductase inhibitors (statins) has been suggested to promote the prevention of AD [189]. A prospective cohort study named the Sacramento Area Latino Study on Aging (SALSA) was conducted among 1789 older ( $\geq 60$ years of age) Mexican American individuals from the Sacramento, CA, area without a previous diagnosis of dementia. Here, Atorvastatin, Cerivastatin, Fluvastatin, Lovastatin were used and statin users were reported about half as likely as those who did not take statins to treat dementia/cognitive impairment (hazard ratio $(\mathrm{HR})=0.52 ; 95 \%$ CI $0.34,0.80)$ during a 5-year follow-up period [190]. Another prospective observational study called the AD Anti-inflammatory Prevention Trial (ADAPT) was observed among 2,233 participants. Here, elective statin use was reported to be correlated with significantly decreased risk of incident $\mathrm{AD}$ that remained unchanged after adjustment for age, gender, education, and APOE genotype [191]. The application of statins was been shown to be correlated with a reduced risk of AD $(\mathrm{HR}=0.57 ; 95 \% \mathrm{CI} 0.37$ to 0.90$)$ in comparison with those that did not take cholesterol-lowering drugs, whereas the use of non-statin cholesterol-lowering drugs was not reported to exert the same correlation. These observations are reported in the largest population-based observational study of this kind which was known as the Rotterdam Study involving 6,992 participants for a mean of 9 years [192]. In a systemic review and meta-analysis of 16 studies in qualitative synthesis and 11 in quantitative synthesis using statins named simvastatin, lovastatin, pravastatin, the researchers demonstrated that long-term data may support beneficial role for statins in the prevention of dementia [193]. Finally, a Cochrane Database systematic review and analysis of doubleblind randomized placebo-controlled trials of statins in people at risk of $\mathrm{AD}$ and dementia conducted two trials with 26,340 participants using simvastatin, pravastatin and demonstrated that statins given to older patients at risk for vascular disease were not beneficial in preventing dementia [194]. Based on the conflicting results of these studies and insufficient evidence, statins cannot be recommended for the purpose of AD-related dementia treatment.

\section{Melatonin}

In experimental models of $\mathrm{AD}$, it was demonstrated that melatonin is detected to exert free radical scavenging, anti-oxidative properties, antiamyloidogenic effects, whereas it weakens tau hyperphosphorylation. All of these properties are supposed to be beneficial in the treatment of $A D$ [195-197]. Again, serotonin which is well-known precursor of melatonin has depleted bit-by-bit and it is reported during the course of AD [198]. Numerous studies have suggested that gold nanoparticles can be beneficial for the early detection and treatment of AD [199]. Music can be a good enhancer in patients with $\mathrm{AD}$ and numerous studies have been conducted to demonstrate its use as an alternative non-pharmacological treatment of AD [200-202].

\section{CURRENT STATUS OF ALZHEIMER'S DISEASE IN BANGLADESH}

A few data are available about the number of $A D$ patient in Bangladesh. There is no precise epidemiological data of AD in this country [203]. Here, the awareness about $\mathrm{AD}$ is now in primary stage. Therefore, affected patient and their family members are facing different problems continuously. The fund for conducting research on $\mathrm{AD}$ is limited. A lower middle income country like Bangladesh is not yet prepared for the management of AD. At present, most of the people of the country are in the young group. However, within 20-30 years there will be huge elder group people in this country. Therefore, there will 
be more chances of occurrences of AD. So, it is high time to think about the disease and its management as a proactive manner and take necessary action in this regard. The policy makers, health professional and allied groups should come forward to make national priority for $\mathrm{AD}$ in Bangladesh.

\section{Smoking rate in Bangladesh}

Bangladesh is one of the largest tobacco consuming countries in the world [204]. It is one of the top ten countries with high current smoking occurrence of $44.7 \%$ among men [205]. It was found that $43.3 \%$ of adults aged 15 years or above use some form of tobacco in Bangladesh. [206].

\section{Obesity levels in Bangladesh}

Almost one-fifth of the Bangladeshi adult population is overweight, according to a global study [207]. This study also said that over the last 33 years, rates of either being overweight or obese doubled among Bangladeshi adults but remained low among children. Another study found that young age obesity is alarmingly high and on rise amongst urban children from wealthy families [208].

\section{CONCLUSION}

In this paper, we assess clinical features of $\mathrm{AD}$, risk and genetic factors, available diagnosis process, the different expressions of pathophysiological mechanisms behind AD and its management through conventional drug therapy, including modern investigational therapeutic strategies, currently introduced and ongoing new insights into the potential therapeutic targets elaborately to figure out complicated AD puzzle. Though numerous clinical trials are designed to open a new door for demystifying the exact reasons of $\mathrm{AD}$, structural and functional influence of various genes associated with $\mathrm{AD}$, fistful information are available in this case. There is no therapy which will terminate the advancement of AD by affecting the origin of disease process, whereas some available non-targeted pharmacological treatment such as anti-inflammatory therapy, metal chelation, antioxidant supplementation, epigenetic modifications can be deleterious due to their improper usage. Choice of inappropriate experimental design, limited population, population heterogeneity, improper use of biomarker in clinical trial, incomplete reporting of data, failure to find suitable compound and significant treatment procedure, failure to use appropriate dosage, etc., can be the major reasons of failure of understanding the neuropathological features of $\mathrm{AD}$ and achieving a definite therapeutic approach.

\section{Future direction}

The number of AD patient is growing day by day. The high occurrence of AD patient is co related with increasing rate of the life expectancy. $\mathrm{AD}$ is a disease causing great sufferings to the patient and their relatives and is also a growing healthcare problem with economical as well as social consequences. There is so far not possible to cure AD but some symptomatic treatment is available. Risk factors can help to identify high-risk individuals who might benefit from different therapeutic outcomes. The focus of dementia research is developing strategy to prevent or delay the onset of dementia [209]. Much of the evidence suggests that the accumulation of $A \beta$ and the abnormal phosphorylation of tau is a reasonable target [210]. However, more targeted treatment approaches are needed to be proposed.

\section{DISCLOSURE STATEMENT}

The authors have no conflicts of interest to disclose.

\section{REFERENCES}

[1] Alzheimer's, Association (2015) Alzheimer's disease facts and figures. Alzheimers Dement 11, 332-384.

[2] Trojanowski JQ, Hampel H (2011) Neurodegenerative disease biomarkers: Guideposts for disease prevention through early diagnosis and intervention. Prog Neurobiol 95, 491-495.

[3] Ridge PG, Ebbert MT, Kauwe JS (2013) Genetics of Alzheimer's disease. Biomed Res Int 2013, 254954.

[4] Blennow K, de Leon MJ, Zetterberg H (2006) Alzheimer's disease. Lancet 368, 387-403.

[5] Petersen RC (2004) Mild cognitive impairment as a diagnostic entity. J Intern Med 256, 183-194.

[6] Qiu C, Kivipelto M, von Strauss E (2009) Epidemiology of Alzheimer's disease: Occurrence, determinants, and strategies toward intervention. Dialogues Clin Neurosci 11, 111-128.

[7] Seeher K, Withall A, Brodaty H (2011) The dementia research mapping project-the 2010 update: Final report. Dementia Collaborative Research Centre, University of New South Wales, Sydney.

[8] Alzheimer's, Association (2016) Alzheimer's disease facts and figures. Alzheimers Dement 12, 459-509.

[9] Draper B (2011) Understanding Alzheimer's and other dementias. Longueville Books, Woollahra. 
[10] American Psychiatric Association (1994) DSM-IV: Diagnostic and Statistics Manual of Mental Disorders, Fourth Edition, Washington, DC.

[11] McKhann GM, Knopman DS, Chertkow H, Hyman BT, Jack CR Jr, Kawas CH, Klunk WE, Koroshetz WJ, Manly JJ, Mayeux R, Mohs RC, Rossor MN, Scheltens P, Carrillo MC, Thies B, Weintraub S, Phelps CH (2011) The diagnosis of dementia due to Alzheimer's disease: Recommendations from the National Institute on Aging-Alzheimer's Association workgroup on diagnostic guidelines for Alzheimer's disease. Alzheimers Dement 7 263-269.

[12] Gorelick PB, Scuteri A, Black SE, DeCarli C, Greenberg SM, Iadecola C, Launer LJ, Laurent S, Lopez OL, Nyenhuis D, Petersen RC, Schneider JA, Tzourio C, Arnett DK, Bennett DA, Chui HC, Higashida RT, Lindquist R, Nilsson PM, Roman GC, Sellke FW, Seshadri S; American Heart Association Stroke Council, Council on Epidemiology and Prevention, Council on Cardiovascular Nursing, Council on Cardiovascular Radiology and Intervention, and Council on Cardiovascular Surgery and Anesthesia (2011) Vascular contributions to cognitive impairment and dementia: A statement for healthcare professionals from the American Heart Association/American Stroke Association. Stroke 42, 2672-2713.

[13] Luchsinger JA, Reitz C, Honig LS, Tang MX, Shea S, Mayeux R (2005) Aggregation of vascular risk factors and risk of incident Alzheimer disease. Neurology 65, 545551.

[14] Kivipelto M, Helkala EL, Laakso MP, Hänninen T, Hallikainen M, Alhainen K, Soininen $\mathrm{H}$, Tuomilehto J, Nissinen A (2001) Midlife vascular risk factors and Alzheimer's disease in later life: Longitudinal, population based study. BMJ 322, 1447-1451.

[15] Yip AG, Brayne C, Matthews FE; MRC Cognitive Function and Ageing Study (2006) Risk factors for incident dementia in England and Wales: The Medical Research Council Cognitive Function and Ageing Study. A population-based nested case-control study. Age Ageing 35, 154-160.

[16] Teunissen CE, de Vente J, Steinbusch HW, De Bruijn C (2002) Biochemical markers related to Alzheimer's dementia in serum and cerebrospinal fluid. Neurobiol Aging 23, 485-508.

[17] Saczynski JS, Pfeifer LA, Masaki K, Korf ES, Laurin D, White L, Launer LJ (2006) The effect of social engagement on incident dementia: The Honolulu-Asia Aging Study. Am J Epidemiol 163, 433-440.

[18] Bennett DA, Schneider JA, Tang Y, Arnold SE, Wilson RS (2006) The effect of social networks on the relation between Alzheimer's disease pathology and level of cognitive function in old people: A longitudinal cohort study. Lancet Neurol 5, 406-412.

[19] Evans DA, Funkenstein HH, Albert MS, Scherr PA, Cook NR, Chown MJ, Hebert LE, Hennekens CH, Taylor JO (1989) Prevalence of Alzheimer's disease in a community population of older persons. Higher than previously reported. JAMA 262, 2551-2556.

[20] Vest RS, Pike CJ (2013) Gender, sex steroid hormones, and Alzheimer's disease. Horm Behav 63, 301-307.

[21] Baumgart M, Snyder HM, Carrillo MC, Fazio S, Kim H, Johns H (2015) Summary of the evidence on modifiable risk factors for cognitive decline and dementia: A population-based perspective. Alzheimers Dement 11, 718-726.
[22] Alzheimer's Association (2013) Alzheimer's disease facts and figures. Alzheimers Dement 9, 208-245.

[23] Fitzpatrick AL, Kuller LH, Lopez OL, Diehr P, O'Meara ES, Longstreth WT Jr, Luchsinger JA (2009) Midlife and late-life obesity and the risk of dementia: Cardiovascular health study. Arch Neurol 66, 336-342.

[24] Gustafson D, Lissner L, Bengtsson C, Björkelund C, Skoog I (2004) A 24-year follow-up of body mass index and cerebral atrophy. Neurology 63, 1876-1881.

[25] Gustafson D, Rothenberg E, Blennow K, Steen B, Skoog I (2003) An 18-year follow-up of overweight and risk of Alzheimer disease. Arch Intern Med 163, 1524-1528.

[26] Gustafson DR, Bäckman K, Waern M, Ostling S, Guo X, Zandi P, Mielke MM, Bengtsson C, Skoog I (2009) Adiposity indicators and dementia over 32 years in Sweden. Neurology 73, 1559-1566.

[27] Qizilbash N, Gregson J, Johnson ME, Pearce N, Douglas I, Wing K, Evans SJ, Pocock SJ (2015) BMI and risk of dementia in two million people over two decades: A retrospective cohort study. Lancet Diabetes Endocrinol 3, 431-436.

[28] Yoshitake T, Kiyohara Y, Kato I, Ohmura T, Iwamoto H, Nakayama K, Ohmori S, Nomiyama K, Kawano H, Ueda K, Sueishi K, Tsuneyoshi M, Fujishima M (1995) Incidence and risk factors of vascular dementia and Alzheimer's disease in a defined elderly Japanese population: The Hisayama Study. Neurology 45, 1161-1168.

[29] Profenno LA, Porsteinsson AP, Faraone SV (2010) Metaanalysis of Alzheimer's disease risk with obesity, diabetes, and related disorders. Biol Psychiatry 67, 505-512.

[30] Besser LM, Gill DP, Monsell SE, Brenowitz W, Meranus DH, Kukull W, Gustafson DR (2014) Body mass index, weight change, and clinical progression in mild cognitive impairment and Alzheimer disease. Alzheimer Dis Assoc Disord 28, 36-43.

[31] Emmerzaal TL, Kiliaan AJ, Gustafson DR (2015) 20032013: A decade of body mass index, Alzheimer's disease, and dementia. J Alzheimers Dis 43, 739-755.

[32] Hughes TF, Borenstein AR, Schofield E, Wu Y, Larson EB (2009) Association between late-life body mass index and dementia: The Kame Project. Neurology 72, 1741-1746.

[33] Green RC, Cupples LA, Go R, Benke KS, Edeki T, Griffith PA, Williams M. Hipps Y, Graff-Radford N, Bachman D, Farrer LA; MIRAGE Study Group (2002) Risk of dementia among white and African American relatives of patients with Alzheimer disease. JAMA 287, 329-336.

[34] Loy CT, Schofield PR, Turner AM, Kwok JB (2014) Genetics of dementia. Lancet 383, 828-840.

[35] Lautenschlager NT, Cupples LA, Rao VS, Auerbach SA, Becker R, Burke J, Chui H, Duara R, Foley EJ, Glatt SL, Green RC, Jones R, Karlinsky H, Kukull WA, Kurz A, Larson EB, Martelli K, Sadovnick AD, Volicer L, Waring SC, Growdon JH, Farrer LA (1996) Risk of dementia among relatives of Alzheimer's disease patients in the MIRAGE Study: What is in store for the oldest old? Neurology 46, 641-650.

[36] Durazzo TC, Mattsson N, Weiner MW; Alzheimer's Disease Neuroimaging Initiative (2014) Smoking and increased Alzheimer's disease risk: A review of potential mechanisms. Alzheimers Dement 10, S122-S145.

[37] Papon MA, Whittington RA, El-Khoury NB, Planel E (2011) Alzheimer's disease and anesthesia. Front Neurosci 4, 272.

[38] Seitz DP, Reimer CL, Siddiqui N (2013) A review of epidemiological evidence for general anesthesia as a risk 
factor for Alzheimer's disease. Prog Neuropsychopharmacol Biol Psychiatry 47, 122-127.

[39] Francis HM, Stevenson RJ (2011) Higher reported saturated fat and refined sugar intake is associated with reduced hippocampal-dependent memory and sensitivity to interoceptive signals. Behav Neurosci 125, 943-955.

[40] Lakhan SE, Kirchgessner A (2013) The emerging role of dietary fructose in obesity and cognitive decline. Nutr $J$ $12,114$.

[41] Moreira PI (2013) High-sugar diets, type 2 diabetes and Alzheimer's disease. Curr Opin Clin Nutr Metab Care 16, 440-445.

[42] Orr ME, Salinas A, Buffenstein R, Oddo S (2014) Mammalian target of rapamycin hyperactivity mediates the detrimental effects of a high sucrose diet on Alzheimer's disease pathology. Neurobiol Aging 35, 1233-1242.

[43] Barnard ND, Bunner AE, Agarwal U (2014) Saturated and trans fats and dementia: A systematic review. Neurobiol Aging 35, S65-S73.

[44] Morris MC, Tangney CC (2014) Dietary fat composition and dementia risk. Neurobiol Aging 35, S59-S64.

[45] Grimm MO, Rothhaar TL, Grösgen S, Burg VK, Hundsdörfer B, Haupenthal VJ, Friess P, Kins S, Grimm HS, Hartmann T (2012) Trans fatty acids enhance amyloidogenic processing of the Alzheimer amyloid precursor protein (APP). J Nutr Biochem 23, 1214-1223.

[46] Oksman M, Iivonen H, Hogyes E, Amtul Z, Penke B, Leenders I, Broersen L, Lütjohann D, Hartmann T, Tanila H (2006) Impact of different saturated fatty acid, polyunsaturated fatty acid and cholesterol containing diets on beta-amyloid accumulation in APP/PS1 transgenic mice. Neurobiol Dis 23, 563-572.

[47] Amtul Z, Westaway D, Cechetto DF, Rozmahel RF (2010) Oleic acid ameliorates amyloidosis in cellular and mouse models of Alzheimer's disease. Brain Pathol 21, 321-329.

[48] Hjorth E, Zhu M, Toro VC, Vedin I, Palmblad J, Cederholm T, Freund-Levi Y, Faxen-Irving G, Wahlund LO, Basun H, Eriksdotter M, Schultzberg M (2013) Omega-3 fatty acids enhance phagocytosis of Alzheimer's diseaserelated amyloid- $\beta 42$ by human microglia and decrease inflammatory markers. J Alzheimers Dis 35, 697-713.

[49] Julien C, Tremblay C, Phivilay A, Berthiaume L, Emond V, Julien P, Calon F (2010) High-fat diet aggravates amyloidbeta and tau pathologies in the $3 \times \mathrm{Tg}$-AD mouse model. Neurobiol Aging 31, 1516-1531.

[50] Lebbadi M, Julien C, Phivilay A, Tremblay C, Emond V, Kang JX, Calon F (2011) Endogenous conversion of omega- 6 into omega-3 fatty acids improves neuropathology in an animal model of Alzheimer's disease. J Alzheimers Dis 27, 853-869.

[51] Zerbi V, Jansen D, Wiesmann M, Fang X, Broersen LM, Veltien A, Heerschap A, Kiliaan AJ (2014) Multinutrient diets improve cerebral perfusion and neuroprotection in a murine model of Alzheimer's disease. Neurobiol Aging 35, 600-613.

[52] Wang HX, Xu W, Pei JJ (2012) Leisure activities, cognition and dementia. Biochim Biophys Acta 1822, 482-491.

[53] Karp A, Paillard-Borg S, Wang HX, Silverstein M, Winblad B, Fratiglioni L (2006) Mental, physical and social components in leisure activities equally contribute to decrease dementia risk. Dement Geriatr Cogn Disord 21, 65-73.

[54] Di Marco LY, Marzo A, Muñoz-Ruiz M, Ikram MA, Kivipelto M, Ruefenacht D, Venneri A, Soininen H, Wanke I, Ventikos YA, Frangi AF (2014) Modifiable lifestyle factors in dementia: A systematic review of longitudinal observational cohort studies. J Alzheimers Dis 42, 119-135.

[55] Sharp ES, Reynolds CA, Pedersen NL, Gatz M (2010) Cognitive engagement and cognitive aging: Is openness protective? Psychol Aging 25, 60-73.

[56] Wilson RS, Boyle PA, Yu L, Barnes LL, Schneider JA, Bennett DA (2013) Life-span cognitive activity, neuropathologic burden, and cognitive aging. Neurology $\mathbf{8 1}$, 314-321.

[57] Hall CB, Lipton RB, Sliwinski M, Katz MJ, Derby CA, Verghese J (2009) Cognitive activities delay onset of memory decline in persons who develop dementia. Neurology 73, 356-361.

[58] Wilson RS, Mendes De Leon CF, Barnes LL, Schneider JA, Bienias JL, Evans DA, Bennett DA (2002) Participation in cognitively stimulating activities and risk of incident Alzheimer disease. JAMA 287, 742-748.

[59] Plassman BL, Havlik RJ, Steffens DC, Helms MJ, Newman TN, Drosdick D, Phillips C, Gau BA, Welsh-Bohmer KA, Burke JR, Guralnik JM, Breitner JC (2000) Documented head injury in early adulthood and risk of Alzheimer's disease and other dementias. Neurology 55, 1158-1166.

[60] Smith DH, Johnson VE, Stewart W (2013) Chronic neuropathologies of single and repetitive TBI: Substrates of dementia? Nat Rev Neurol 9, 211-221.

[61] Lehman EJ, Hein MJ, Baron SL, Gersic CM (2012) Neurodegenerative causes of death among retired National Football League players. Neurology 79, 1970-1974.

[62] McKee AC, Stein TD, Nowinski CJ, Stein TD, Alvarez VE, Daneshvar DH, Lee HS, Wojtowicz SM, Hall G, Baugh CM, Riley DO, Kubilus CA, Cormier KA, Jacobs MA, Martin BR, Abraham CR, Ikezu T, Reichard RR, Wolozin BL, Budson AE, Goldstein LE, Kowall NW, Cantu RC (2013) The spectrum of disease in chronic traumatic encephalopathy. Brain 136, 43-64.

[63] Monti JM, Voss MW, Pence A, McAuley E, Kramer AF, Cohen NJ (2013) History of mild traumatic brain injury is associated with deficits in relational memory, reduced hippocampal volume, and less neural activity later in life. Front Aging Neurosci 5, 41.

[64] Lott IT, Dierssen M (2010) Cognitive deficits and associated neurological complications in individuals with Down's syndrome. Lancet Neurol 9, 623-633.

[65] Karch CM, Cruchaga C, Goate AM (2014) Alzheimer's disease genetics: From the bench to the clinic. Neuron 83, 11-26.

[66] Corder EH, Saunders AM, Strittmatter WJ, Schmechel DE, Gaskell PC, Small GW, Roses AD, Haines JL, Pericak-Vance MA (1993) Gene dose of apolipoprotein E type 4 allele and the risk of Alzheimer's disease in late onset families. Science 261, 921-923.

[67] Strittmatter WJ, Weisgraber KH, Huang DY, Dong LM, Salvesen GS, Pericak-Vance M, Schmechel D, Saunders AM, Goldgaber D, Roses AD (1993) Binding of human apolipoprotein $\mathrm{E}$ to synthetic amyloid beta peptide: Isoform-specific effects and implications for late-onset Alzheimer disease. Proc Natl Acad Sci U S A 90, 80988102.

[68] Talwar P, Sinha J, Grover S, Agarwal R, Kushwaha S, Srivastava MV, Kukreti R (2016) Meta-analysis of apolipoprotein $\mathrm{E}$ levels in the cerebrospinal fluid of patients with Alzheimer's disease. J Neurol Sci 360, 179187. 
[69] Mahley RW, Weisgraber KH, Huang Y (2006) Apolipoprotein E4: A causative factor and therapeutic target in neuropathology, including Alzheimer's disease. Proc Natl Acad Sci U S A 103, 5644-5651.

[70] Huang Y, Weisgraber KH, Mucke L, Mahley RW (2004) Apolipoprotein E: Diversity of cellular origins, structural and biophysical properties, and effects in Alzheimer's disease. J Mol Neurosci 23, 189-204.

[71] Karch CM, Goate AM (2015) Alzheimer's disease risk genes and mechanisms of disease pathogenesis. Biol Psychiatry 77, 43-51.

[72] Pericak-Vance MA, Bebout JL, Gaskell PC Jr, Yamaoka LH, Hung WY, Alberts MJ, Walker AP, Bartlett RJ, Haynes CA, Welsh KA, Earl NL, Heyman A, Clark CM, Roses AD (1991) Linkage studies in familial Alzheimer disease: Evidence for chromosome 19 linkage. Am J Hum Genet 48, 1034-1050.

[73] Siest G, Pillot T, Régis-Bailly A, Leininger-Muller B, Steinmetz J, Galteau MM, Visvikis S (1995) Apolipoprotein E: An important gene and protein to follow in laboratory medicine. Clin Chem 41, 1068-1086.

[74] Mahley RW (1988) Apolipoprotein E: Cholesterol transport protein with expanding role in cell biology. Science 240, 622-630.

[75] Kanekiyo T, Xu H, Bu G (2014) ApoE and A $\beta$ in Alzheimer's disease: Accidental encounters or partners? Neuron 81, 740-754.

[76] Bu G (2009) Apolipoprotein E and its receptors in Alzheimer's disease: Pathways, pathogenesis and therapy. Nat Rev Neurosci 10, 333-344.

[77] Liu CC, Liu CC, Kanekiyo T, Xu H, Bu G (2013) Apolipoprotein E and Alzheimer disease: Risk, mechanisms and therapy. Nat Rev Neurol 9, 106-118.

[78] Guerreiro RJ, Gustafson DR, Hardy J (2012) The genetic architecture of Alzheimer's disease: Beyond APP, PSENs and APOE. Neurobiol Aging 33, 437-456.

[79] Goldgaber D, Lerman MI, McBride OW, Saffiotti U, Gajdusek DC (1987) Characterization and chromosomal localization of a cDNA encoding brain amyloid of Alzheimer's disease. Science 235, 877-880.

[80] Kang J, Lemaire HG, Unterbeck A, Salbaum JM, Masters CL, Grzeschik KH, Multhaup G, Beyreuther K, Müller-Hill B (1987) The precursor of Alzheimer's disease amyloid A4 protein resembles a cell-surface receptor. Nature 325, 733-736.

[81] Robakis NK, Wisniewski HM, Jenkins EC, Devine-Gage EA, Houck GE, Yao XL, Ramakrishna N, Wolfe G, Silverman WP, Brown WT (1987) Chromosome 21q21 sublocalisation of gene encoding beta-amyloid peptide in cerebral vessels and neuritic (senile) plaques of people with Alzheimer disease and Down syndrome. Lancet 1, 384-385.

[82] Tanzi RE, Gusella JF, Watkins PC, Bruns GA, St GeorgeHyslop P, Van Keuren ML, Patterson D, Pagan S, Kurnit DM, Neve RL (1987) Amyloid beta protein gene: cDNA, mRNA distribution, and genetic linkage near the Alzheimer locus. Science 235, 880-884.

[83] Karch CM, Jeng AT, Nowotny P, Cady J, Cruchaga C, Goate AM (2012) Expression of novel Alzheimer's disease risk genes in control and Alzheimer's disease brains. PLoS One 7, e50976.

[84] Bekris LM, Yu CE, Bird TD, Tsuang DW (2010) Genetics of Alzheimer disease. J Geriatr Psychiatry Neurol 23, 213227.
[85] Koo EH, Squazzo SL (1994) Evidence that production and release of amyloid beta-protein involves the endocytic pathway. J Biol Chem 269, 17386-17389.

[86] Bossy-Wetzel E, Schwarzenbacher R, Lipton SA (2004) Molecular pathways to neurodegeneration. Nat Med 10, S2-S9.

[87] De Strooper B, Saftig P, Craessaerts K, Vanderstichele H, Guhde G, Annaert W, Von Figura K, Van Leuven F (1998) Deficiency of presenilin-1 inhibits the normal cleavage of amyloid precursor protein. Nature 391, 387-390.

[88] Cruts M, Hendriks L, Van Broeckhoven C (1996) The presenilin genes: A new gene family involved in Alzheimer disease pathology. Hum Mol Genet 5, 1449-1455.

[89] Baulac S, LaVoie MJ, Kimberly WT, Strahle J, Wolfe MS, Selkoe DJ, Xia W (2003) Functional gamma-secretase complex assembly in Golgi/trans-Golgi network: Interactions among presenilin, nicastrin, Aph1, Pen-2, and gamma-secretase substrates. Neurobiol Dis 14, 194-204.

[90] De Strooper B (2003) Aph-1, Pen-2, and Nicastrin with Presenilin generate an active gamma-secretase complex. Neuron 38, 9-12.

[91] Kaminski WE, Orsó E, Diederich W, Klucken J, Drobnik W, Schmitz G (2000) Identification of a novel human sterol-sensitive ATP-binding cassette transporter (ABCA7). Biochem Biophys Res Commun 273, 532-538.

[92] Broccardo C, Osorio J, Luciani MF, Schriml LM, Prades C, Shulenin S, Arnould I, Naudin L, Lafargue C, Rosier M, Jordan B, Mattei MG, Dean M, Denéfle P, Chimini G (2001) Comparative analysis of the promoter structure and genomic organization of the human and mouse ABCA7 gene encoding a novel ABCA transporter. Cytogenet Cell Genet 92, 264-270.

[93] Ikeda Y, Abe-Dohmae S, Munehira Y, Aoki R, Kawamoto S, Furuya A, Shitara K, Amachi T, Kioka N, Matsuo M, Yokoyama S, Ueda K (2003) Posttranscriptional regulation of human $\mathrm{ABCA} 7$ and its function for the apoAI-dependent lipid release. Biochem Biophys Res Commun 311, 313-318.

[94] Jehle AW, Gardai SJ, Li S, Linsel-Nitschke P, Morimoto K, Janssen WJ, Vandivier RW, Wang N, Greenberg S, Dale BM, Qin C, Henson PM, Tall AR (2006) ATP-binding cassette transporter A7 enhances phagocytosis of apoptotic cells and associated ERK signaling in macrophages. J Cell Biol 174, 547-556.

[95] Chan SL, Kim WS, Kwok JB, Hill AF, Cappai R, Rye KA, Garner B (2008) ATP-binding cassette transporter A7 regulates processing of amyloid precursor protein in vitro. J Neurochem 106, 793-804.

[96] Lin JW, Wyszynski M, Madhavan R, Sealock R, Kim JU, Sheng M (1998) Yotiao, a novel protein of neuromuscular junction and brain that interacts with specific splice variants of NMDA receptor subunit NR1. J Neurosci 18, 2017-2027.

[97] Westphal RS, Tavalin SJ, Lin JW, Alto NM, Fraser ID, Langeberg LK, Sheng M, Scott JD (1999) Regulation of NMDA receptors by an associated phosphatase-kinase signaling complex. Science 285, 93-96.

[98] Chouraki V, Seshadri S (2014) Genetics of Alzheimer's disease. Adv Genet 87, 245-294.

[99] Ren G, Vajjhala P, Lee JS, Winsor B, Munn AL (2006) The BAR domain proteins: Molding membranes in fission, fusion, and phagy. Microbiol Mol Biol Rev 70, 37-120.

[100] Sakamuro D, Elliott KJ, Wechsler-Reya R, Prendergast GC (1996) BIN1 is a novel MYC-interacting protein with features of a tumor suppressor. Nat Genet 14, 69-77. 
[101] Harold D, Abraham R, Hollingworth P, Sims R, Gerrish A, Hamshere ML, Pahwa JS, Moskvina V, Dowzell K, Williams A, Jones N, Thomas C, Stretton A, Morgan AR, Lovestone S, Powell J, Proitsi P, Lupton MK, Brayne C, Rubinsztein DC, Gill M, Lawlor B, Lynch A, Morgan K, Brown KS, Passmore PA, Craig D, McGuinness B, Todd S, Holmes C, Mann D, Smith AD, Love S, Kehoe PG, Hardy J, Mead S, Fox N, Rossor M, Collinge J, Maier W, Jessen F, Schürmann B, Heun R, van den Bussche H, Heuser I, Kornhuber J, Wiltfang J, Dichgans M, Frölich L, Hampel H, Hüll M, Rujescu D, Goate AM, Kauwe JS, Cruchaga C, Nowotny P, Morris JC, Mayo K, Sleegers K, Bettens K, Engelborghs S, De Deyn PP, Van Broeckhoven C, Livingston G, Bass NJ, Gurling H, McQuillin A, Gwilliam R, Deloukas P, Al-Chalabi A, Shaw CE, Tsolaki M, Singleton $\mathrm{AB}$, Guerreiro R, Mühleisen TW, Nöthen MM, Moebus S, Jöckel KH, Klopp N, Wichmann HE, Carrasquillo MM, Pankratz VS, Younkin SG, Holmans PA, O'Donovan M, Owen MJ, Williams J (2009) Genome-wide association study identifies variants at CLU and PICALM associated with Alzheimer's disease. Nat Genet 41, 1088-1093.

[102] Naj AC, Jun G, Beecham GW, Wang LS, Vardarajan BN, Buros J, Gallins PJ, Buxbaum JD, Jarvik GP, Crane PK, Larson EB, Bird TD, Boeve BF, Graff-Radford NR, De Jager PL, Evans D, Schneider JA, Carrasquillo MM, Ertekin-Taner N, Younkin SG, Cruchaga C, Kauwe JS, Nowotny P, Kramer P, Hardy J, Huentelman MJ, Myers AJ, Barmada MM, Demirci FY, Baldwin CT, Green RC, Rogaeva E, St George-Hyslop P, Arnold SE, Barber R, Beach T, Bigio EH, Bowen JD, Boxer A, Burke JR, Cairns NJ, Carlson CS, Carney RM, Carroll SL, Chui HC, Clark DG, Corneveaux J, Cotman CW, Cummings JL, DeCarli C, DeKosky ST, Diaz-Arrastia R, Dick M, Dickson DW, Ellis WG, Faber KM, Fallon KB, Farlow MR, Ferris S, Frosch MP, Galasko DR, Ganguli M, Gearing M, Geschwind DH, Ghetti B, Gilbert JR, Gilman S, Giordani B, Glass JD, Growdon JH, Hamilton RL, Harrell LE, Head E, Honig LS, Hulette CM, Hyman BT, Jicha GA, Jin LW, Johnson N, Karlawish J, Karydas A, Kaye JA, Kim R, Koo EH, Kowall NW, Lah JJ, Levey AI, Lieberman AP, Lopez OL, Mack WJ, Marson DC, Martiniuk F, Mash DC, Masliah E, McCormick WC, McCurry SM, McDavid AN, McKee AC, Mesulam M, Miller BL, Miller CA, Miller JW, Parisi JE, Perl DP, Peskind E, Petersen RC, Poon WW, Quinn JF, Rajbhandary RA, Raskind M, Reisberg B, Ringman JM, Roberson ED, Rosenberg RN, Sano M, Schneider LS, Seeley W, Shelanski ML, Slifer MA, Smith CD, Sonnen JA, Spina S, Stern RA, Tanzi RE, Trojanowski JQ, Troncoso JC, Van Deerlin VM, Vinters HV, Vonsattel JP, Weintraub S, Welsh-Bohmer KA, Williamson J, Woltjer RL, Cantwell LB, Dombroski BA, Beekly D, Lunetta KL, Martin ER, Kamboh MI, Saykin AJ, Reiman EM, Bennett DA, Morris JC, Montine TJ, Goate AM, Blacker D, Tsuang DW, Hakonarson H, Kukull WA, Foroud TM, Haines JL, Mayeux R, Pericak-Vance MA, Farrer LA, Schellenberg GD (Genet) (2011) Common variants at MS4A4/MS4A6E, CD2AP, CD33 and EPHA1 are associated with late-onset Alzheimer's disease. Nature 43, 436-441.

[103] English JA, Dicker P, Föcking M, Dunn MJ, Cotter DR (2009) 2-D DIGE analysis implicates cytoskeletal abnormalities in psychiatric disease. Proteomics 9, 3368-3382.

[104] Yang S, Liu T, Li S, Zhang X, Ding Q, Que H, Yan X, Wei $\mathrm{K}$, Liu S (2008) Comparative proteomic analysis of brains of naturally aging mice. Neuroscience 154, 1107-1120.
[105] Thinakaran G, Koo EH (2008) Amyloid precursor protein trafficking, processing, and function. J Biol Chem 283, 29615-29619.

[106] Galderisi U, Di Bernardo G, Cipollaro M, Jori FP, Piegari E, Cascino A, Peluso G, Melone MA (1999) Induction of apoptosis and differentiation in neuroblastoma and astrocytoma cells by the overexpression of Bin1, a novel Myc interacting protein. $J$ Cell Biochem 74, 313-322.

[107] Tan MS, Yu JT, Tan L (2013) Bridging integrator 1 (BIN1): Form, function, and Alzheimer's disease. Trends Mol Med 19, 594-603.

[108] Pant S, Sharma M, Patel K, Caplan S, Carr CM, Grant BD (2009) AMPH-1/Amphiphysin/Bin1 functions with RME-1/Ehd1 in endocytic recycling. Nat Cell Biol 11, 1399-1410.

[109] Wixler V, Laplantine E, Geerts D, Sonnenberg A, Petersohn D, Eckes B, Paulsson M, Aumailley M (1999) Identification of novel interaction partners for the conserved membrane proximal region of alpha-integrin cytoplasmic domains. FEBS Lett 445, 351-355.

[110] Kirsch KH, Georgescu MM, Ishimaru S, Hanafusa H (1999) CMS: An adapter molecule involved in cytoskeletal rearrangements. Proc Natl Acad Sci U S A 96, 6211-6216.

[111] Dustin ML, Olszowy MW, Holdorf AD, Li J, Bromley S, Desai N, Widder P, Rosenberger F, van der Merwe PA, Allen PM, Shaw AS (1998) A novel adaptor protein orchestrates receptor patterning and cytoskeletal polarity in T-cell contacts. Cell 94, 667-677.

[112] Lehtonen S, Zhao F, Lehtonen E (2002) CD2-associated protein directly interacts with the actin cytoskeleton. Am J Physiol Renal Physiol 283, F734-F743.

[113] Cormont M, Metón I, Mari M, Monzo P, Keslair F, Gaskin C, McGraw TE, Le Marchand-Brustel Y (2003) $\mathrm{CD} 2 \mathrm{AP} / \mathrm{CMS}$ regulates endosome morphology and traffic to the degradative pathway through its interaction with Rab4 and c-Cbl. Traffic 4, 97-112.

[114] Kobayashi S, Sawano A, Nojima Y, Shibuya M, Maru Y (2004) The c-Cbl/CD2AP complex regulates VEGFinduced endocytosis and degradation of Flt-1 (VEGFR-1). FASEB J 18, 929-931.

[115] Wolf G, Stahl RA (2003) CD2-associated protein and glomerular disease. Lancet 362, 1746-1748.

[116] Calabia-Linares C, Robles-Valero J, de la Fuente H, Perez-Martinez M, Martín-Cofreces N, Alfonso-Pérez M, Gutierrez-Vázquez C, Mittelbrunn M, Ibiza S, UrbanoOlmos FR, Aguado-Ballano C, Sánchez-Sorzano CO, Sanchez-Madrid F, Veiga E (2011) Endosomal clathrin drives actin accumulation at the immunological synapse. J Cell Sci 124, 820-830.

[117] Jones SE, Jomary C (2002) Clusterin. Int J Biochem Cell Biol 34, 427-431.

[118] Rizzi F, Caccamo AE, Belloni L, Bettuzzi S (2009) Clusterin is a short half-life, poly-ubiquitinated protein, which controls the fate of prostate cancer cells. J Cell Physiol 219, 314-323.

[119] Oda T, Wals P, Osterburg HH, Johnson SA, Pasinetti GM, Morgan TE, Rozovsky I, Stine WB, Snyder SW, Holzman TF, Krafft GA, Finch CA (1995) Clusterin (apoJ) alters the aggregation of amyloid beta-peptide (A beta 1-42) and forms slowly sedimenting A beta complexes that cause oxidative stress. Exp Neurol 136, 22-31.

[120] Matsubara E, Soto C, Governale S, Frangione B, Ghiso J (1996) Apolipoprotein J and Alzheimer's amyloid beta solubility. Biochem J 316, 671-679. 
[121] Griciuc A, Serrano-Pozo A, Parrado AR, Lesinski AN, Asselin CN, Mullin K, Hooli B, Choi SH, Hyman BT, Tanzi RE (2013) Alzheimer's disease risk gene CD33 inhibits microglial uptake of amyloid beta. Neuron 78, 631-643.

[122] Simón AM, de Maturana RL, Ricobaraza A, Escribano L, Schiapparelli L, Cuadrado-Tejedor M, Pérez-Mediavilla A, Avila J, Del Río J, Frechilla D (2009) Early changes in hippocampal Eph receptors precede the onset of memory decline in mouse models of Alzheimer's disease. J Alzheimers Dis 17, 773-786.

[123] Rogaeva E, Meng Y, Lee JH, Gu Y, Kawarai T, Zou F, Katayama T, Baldwin CT, Cheng R, Hasegawa H, Chen F, Shibata N, Lunetta KL, Pardossi-Piquard R, Bohm C, Wakutani Y, Cupples LA, Cuenco KT, Green RC, Pinessi L, Rainero I, Sorbi S, Bruni A, Duara R, Friedland RP, Inzelberg R, Hampe W, Bujo H, Song YQ, Andersen OM, Willnow TE, Graff-Radford N, Petersen RC, Dickson D, Der SD, Fraser PE, Schmitt-Ulms G, Younkin S, Mayeux R, Farrer LA, St George-Hyslop P (Genet) (2007) The neuronal sortilin-related receptor SORL1 is genetically associated with Alzheimer disease. Nature 39, 168-177.

[124] Lee JH, Cheng R, Honig LS, Vonsattel JG, Clark L, Mayeux R (2008) Association between genetic variants in SORL1 and autopsy-confirmed Alzheimer disease. $\mathrm{Neu}$ rology 70, 887-889.

[125] Andersen OM, Reiche J, Schmidt V, Gotthardt M, Spoelgen R, Behlke J, von Arnim CA, Breiderhoff T, Jansen P, Wu X, Bales KR, Cappai R, Masters CL, Gliemann J, Mufson EJ, Hyman BT, Paul SM, Nykjaer A, Willnow TE (2005) Neuronal sorting protein-related receptor sorLA/LR11 regulates processing of the amyloid precursor protein. Proc Natl Acad Sci U S A 102, 13461-13466.

[126] Reitz C, Cheng R, Rogaeva E, Lee JH, Tokuhiro S, Zou F, Bettens K, Sleegers, K, Tan EK, Kimura R, Shibata N, Arai H, Kamboh MI, Prince JA, Maier W, Riemenschneider M, Owen M, Harold D, Hollingworth P, Cellini E, Sorbi S, Nacmias B, Takeda M, Pericak-Vance MA, Haines JL, Younkin S, Williams J, van Broeckhoven C, Farrer LA, St George-Hyslop PH, Mayeux R; Genetic and Environmental Risk in Alzheimer Disease1 Consortium (2011) Meta-analysis of the association between variants in SORL1 and Alzheimer disease. Arch Neurol 68, 99-106.

[127] Rohn TT (2013) The triggering receptor expressed on myeloid cells 2: "TREM-ming" the inflammatory component associated with Alzheimer's disease. Oxid Med Cell Longev 2013, 860959.

[128] Colonna M (2003) TREMs in the immune system and beyond. Nat Rev Immunol 3, 445-453.

[129] Buée L, Bussière T, Buée-Scherrer V, Delacourte A, Hof PR (2000) Tau protein isoforms, phosphorylation and role in neurodegenerative disorders. Brain Res Brain Res Rev 33, 95-130.

[130] Pedersen JT, Sigurdsson EM (2015) Tau immunotherapy for Alzheimer's disease. Trends Mol Med 21, 394-402.

[131] Shin RW, Iwaki T, Kitamoto T, Tateishi J (1991) Hydrated autoclave pretreatment enhances tau immunoreactivity in formalin-fixed normal and Alzheimer's disease brain tissues. Lab Invest 64, 693-702.

[132] Hoozemans JJ, Veerhuis R, Van Haastert ES, Rozemuller JM, Baas F, Eikelenboom P, Scheper W (2005) The unfolded protein response is activated in Alzheimer's disease. Acta Neuropathol 110, 165-172.
[133] López Salon M, Morelli L, Castaño EM, Soto EF, Pasquini JM (2000) Defective ubiquitination of cerebral proteins in Alzheimer's disease. J Neurosci Res 62, 302-310.

[134] Archangelo LF, Gläsner J, Krause A, Bohlander SK (2006) The novel CALM interactor CATS influences the subcellular localization of the leukemogenic fusion protein CALM/AF10. Oncogene 25, 4099-4109.

[135] Morris MC, Tangney CC, Wang Y, Sacks FM, Barnes LL, Bennett DA, Aggarwal NT (2015) MIND diet slows cognitive decline with aging. Alzheimers Dement 11, 1015-1022.

[136] Vemuri P, Wiste HJ, Weigand SD, Shaw LM, Trojanowski JQ, Weiner MW, Knopman DS, Petersen RC, Jack CR, Jr (2009) Alzheimer's Disease Neuroimaging Initiative, MRI and CSF biomarkers in normal, MCI, and AD subjects: Diagnostic discrimination and cognitive correlations. Neurology 73, 287-293.

[137] Vemuri P, Wiste HJ, Weigand SD, Shaw LM, Trojanowski JQ, Weiner MW, Knopman DS, Petersen RC, Jack CR, Jr, Alzheimer's Disease Neuroimaging Initiative (2009) MRI and CSF biomarkers in normal, MCI, and AD subjects: Predicting future clinical change. Neurology 73, 294-301.

[138] Zhang D, Wang Y, Zhou L, Yuan H, Shen D; Alzheimer's Disease Neuroimaging Initiative (2011) Multimodal classification of Alzheimer's disease and mild cognitive impairment. Neuroimage 55, 856-867.

[139] McKhann GM, Albert MS, Sperling RA (2012) Changing diagnostic concepts of Alzheimer's disease. In Alzheimer's disease-Modernizing concept, biological diagnosis and therapy, Karger, Basel, Switzerland, pp. 115-121.

[140] Bloudek LM, Spackman DE, Blankenburg M, Sullivan SD (2011) Review and meta-analysis of biomarkers and diagnostic imaging in Alzheimer's disease. J Alzheimers Dis 26, 627-645.

[141] Kumar A, Dogra S (2008) Neuropathology and therapeutic management of Alzheimer's disease - An update. Drugs Future 33, 433-446.

[142] Kurz A, Perneczky R (2011) Novel insights for the treatment of Alzheimer's disease. Prog Neuropsychopharmacol Biol Psychiatry 35, 373-379.

[143] Anand R, Gill KD, Mahdi AA (2014) Therapeutics of Alzheimer's disease: Past, present and future. Neuropharmacology 76, 27-50.

[144] Selkoe DJ (2001) Alzheimer's disease: Genes, proteins, and therapy. Physiol Rev 81, 741-766.

[145] Querfurth HW, Laferla FM (2010) Alzheimer's disease. $N$ Engl J Med 362, 329-344.

[146] Hardy J (2009) The amyloid hypothesis for Alzheimer's disease: A critical reappraisal. J Neurochem 110, 11291134.

[147] Dal Prá I, Chiarini A, Gui L, Chakravarthy B, Pacchiana R, Gardenal E, Whitfield JF, Armato U (2015) Do astrocytes collaborate with neurons in spreading the "infectious" A $\beta$ and Tau drivers of Alzheimer's disease? Neuroscientist 21, 9-29.

[148] Galimberti D, Ghezzi L, Scarpini E (2013) Immunotherapy against amyloid pathology in Alzheimer's disease. J Neurol Sci 333, 50-54.

[149] Hardy J, Selkoe DJ (2002) The amyloid hypothesis of Alzheimer's disease: Progress and problems on the road to therapeutics. Science 297, 353-356.

[150] Ghosh AK, Brindisi M, Tang J (2012) Developing $\beta$ secretase inhibitors for treatment of Alzheimer's disease. J Neurochem 120, 71-83. 
[151] Chang WP, Huang X, Downs D, Cirrito JR, Koelsch G, Holtzman DM, Ghosh AK, Tang J (2011) Beta-secretase inhibitor GRL-8234 rescues age related cognitive decline in APP transgenic mice. FASEB J 25, 775-784.

[152] Mitani Y, Yarimizu J, Saita K, Uchino H, Akashiba H, Shitaka Y, Ni K, Matsuoka N (2012) Differential effects between $\gamma$ secretase inhibitors and modulators on cognitive function in amyloid precursor protein-transgenic and nontransgenic mice. J Neurosci 32, 2037-2050.

[153] Bateman RJ, Siemers ER, Mawuenyega KG, Wen G, Browning KR, Sigurdson WC, Yarasheski KE, Friedrich SW, Demattos RB, May PC, Paul SM, Holtzman DM (2009) A gamma secretase inhibitor decreases amyloidbeta production in the central nervous system. Ann Neurol 66, 48-54.

[154] Henley DB, May PC, Dean RA, Siemers ER (2009) Development of semagacestat (LY450139), a functional gamma-secretase inhibitor, for the treatment of Alzheimer's disease. Exp Opin Pharmacother 10, 16571664.

[155] Yesuvadian R, Krishnamoorthy J, Ramamoorthy A, Bhunia A (2014) Potent $\gamma$-secretase inhibitors/modulators interact with amyloid- $\beta$ fibrils but do not inhibit fibrillation: A high-resolution NMR study. Biochem Biophys Res Commun 447, 590-595.

[156] Tomita T (2009) Secretase inhibitors and modulators for Alzheimer's disease treatment. Expert Rev Neurother 9, 661-679.

[157] Griffiths HH, Morten IJ, Hooper NM (2008) Emerging and potential therapies for Alzheimer's disease. Expert Opin Ther Targets 12, 693-704.

[158] Tang J, Xu H, Fan X, Li D, Rancourt D, Zhou G, Li Z, Yang L (2008) Embryonic stem cell-derived neural precursor cells improve memory dysfunction in Abeta (1-40) injured rats. Neurosci Res 62, 86-96.

[159] Zheng MQ, Yin DZ, Zhang L, Lei B, Cheng DF, Cai HC, Han YJ, Wu MX, Zhang H, Wang J (2008) Biological characters of [18F]O-FEt-PIB in a rat model of Alzheimer's disease using micro-PET imaging. Acta Pharmacol Sin 29, 548-554.

[160] Han M, Feng Y, Sun YY (2010) Preparation of small molecule compounds for promoting stem cells hyperplasia. PCT Int Appl 41 pp. WO 2010130063, A1 20101118, CAN 153:643462.

[161] Hawkes CA, Ng V, McLaurin J (2009) Small molecule inhibitors of A $\beta$-aggregation and neurotoxicity. Drug Dev Res 70, 111-124.

[162] Seo JS, Kim TK, Leem YH, Lee KW, Park SK, Baek IS, Kim KS, Im GJ, Lee SM, Park YH, Han PL (2009) SKPC-B70M confers anti-oxidant activity and reduces Abeta levels in the brain of Tg2576 mice. Brain Res 1261, 100108.

[163] Liu G, Huang W, Moir RD, Vanderburg CR, Lai B, Peng Z, Tanzi RE, Rogers JT, Huang X (2006) Metal exposure and Alzheimer pathogenesis. J Struct Biol 155, 45-51.

[164] Kenche VB, Barnham KJ (2011) Alzheimer's disease and metals: Therapeutic opportunities. Br J Pharmacol 163, 211-219.

[165] Crouch PJ, Barnham KJ (2012) Therapeutic redistribution of metal ions to treat Alzheimer's disease. Acc Chem Res 45, 1604-1611.

[166] Belyaev ND, Nalivaeva NN, Makova NZ, Turner AJ (2009) Neprilysin gene expression requires binding of the amyloid precursor protein intracellular domain to its promoter: Implications for Alzheimer disease. EMBO Rep 10, 94-100.

[167] Lemere CA (2013) Immunotherapy for Alzheimer's disease: Hoops and hurdles. Mol Neurodegener 8, 36 .

[168] Wisniewski T, Goñi F (2014) Immunotherapy for Alzheimer's disease. Biochem Pharmacol 88, 499-507.

[169] Nicoll JA, Wilkinson D, Holmes C, Steart P, Markham H, Weller RO (2003) Neuropathology of human Alzheimer disease after immunization with amyloid-beta peptide: A case report. Nat Med 9, 448-452.

[170] Masliah E, Hansen L, Adame A, Crews L, Bard F, Lee C, Seubert P, Games D, Kirby L, Schenk D (2005) Abeta vaccination effects on plaque pathology in the absence of encephalitis in Alzheimer disease. Neurology 64, 129-131.

[171] Ferrer I, Boada Rovira M, Sánchez Guerra ML, Rey MJ, Costa-Jussá F (2004) Neuropathology and pathogenesis of encephalitis following amyloid-beta immunization in Alzheimer's disease. Brain Pathol 14, 11-20.

[172] Gilman S, Koller M, Black RS, Jenkins L, Griffith SG, Fox NC, Eisner L, Kirby L, Rovira MB, Forette F, Orgogozo JM; AN1792(QS-21)-201 Study Team (2005) Clinical effects of Abeta immunization (AN1792) in patients with AD in an interrupted trial. Neurology 64, 1553-1562.

[173] Frazer ME, Hughes JE, Mastrangelo MA, Tibbens JL, Federoff HJ, Bowers WJ (2008) Reduced pathology and improved behavioral performance in Alzheimer's disease mice vaccinated with HSV amplicons expressing amyloidbeta and interleukin-4. Mol Ther 16, 845-853.

[174] Benedetti F, Bollettini I, Barberi I, Radaelli D, Poletti S, Locatelli C, Pirovano A, Lorenzi C, Falini A, Colombo C, Smeraldi E (2013) Lithium and GSK3- $\beta$ promoter gene variants influence white matter microstructure in bipolar disorder. Neuropsychopharmacology 38, 313-327.

[175] Dill J, Wang H, Zhou F, Li S (2008) Inactivation of glycogen synthase kinase 3 promotes axonal growth and recovery in the CNS. J Neurosci 28, 8914-8928.

[176] Engel T, Goñi-Oliver P, Lucas JJ, Avila J, Hernández F (2006) Chronic lithium administration to FTDP-17 tau and GSK-3beta overexpressing mice prevents tau hyperphosphorylation and neurofibrillary tangle formation, but pre-formed neurofibrillary tangles do not revert. $\mathrm{J} \mathrm{Neu}$ rochem $\mathbf{9 9}, 1445-1455$.

[177] Noble W, Planel E, Zehr C, Olm V, Meyerson J, Suleman F, Gaynor K, Wang L, LaFrancois J, Feinstein B, Burns M, Krishnamurthy P, Wen Y, Bhat R, Lewis J, Dickson D, Duff K (2005) Inhibition of glycogen synthase kinase-3 by lithium correlates with reduced tauopathy and degeneration in vivo. Proc Natl Acad Sci U S A 102, 6990-6995.

[178] Hampel H, Ewers M, Bürger K, Annas P, Mörtberg A, Bogstedt A, Frölich L, Schröder J, Schönknecht P, Riepe MW, Kraft I, Gasser T, Leyhe T, Möller HJ, Kurz A, Basun H (2009) Lithium trial in Alzheimer's disease: A randomized, single-blind, placebo-controlled, multicenter 10-week study. J Clin Psychiatry 70, 922-931.

[179] Selenica ML, Jensen HS, Larsen AK, Pedersen ML, Helboe L, Leist M, Lotharius J (2007) Efficacy of smallmolecule glycogen synthase kinase-3 inhibitors in the postnatal rat model of tau hyperphosphorylation. $\mathrm{Br} J$ Pharmacol 152, 959-979.

[180] Hwang SH, Shin EJ, Shin TJ, Lee BH, Choi SH, Kang J, Kim HJ, Kwon SH, Jang CG, Lee JH, Kim HC, Nah SY (2012) Gintonin, a ginseng-derived lysophosphatidic acid receptor ligand, attenuates Alzheimer's disease-related neuropathies: Involvement of non-amyloidogenic processing. J Alzheimers Dis 31, 207-223. 
[181] Chen F, Eckman EA, Eckman CB (2006) Reductions in levels of the Alzheimer's amyloid beta peptide after oral administration of ginsenosides. FASEB J 20, 1269-1271.

[182] Tian X, Zhang L, Wang J, Dai J, Shen S, Yang L, Huang P (2013) The protective effect of hyperbaric oxygen and Ginkgo biloba extract on A $\beta 25$-35-induced oxidative stress and neuronal apoptosis in rats. Behav Brain Res 242, 1-8.

[183] Luo Y, Smith JV, Paramasivam V, Burdick A, Curry KJ, Buford JP, Khan I, Netzer WJ, Xu H, Butko P (2002) Inhibition of amyloid-beta aggregation and caspase-3 activation by the Ginkgo biloba extract EGb761. Proc Natl Acad Sci U S A 99, 12197-12202.

[184] Le Bars PL, Velasco FM, Ferguson JM, Dessain EC, Kieser M, Hoerr R (2002) Influence of the severity of cognitive impairment on the effect of the Ginkgo biloba extract EGb 761 in Alzheimer's disease. Neuropsychobiology 45, 19-26.

[185] Kuboyama T, Tohda C, Komatsu K (2005) Neuritic regeneration and synaptic reconstruction induced by withanolide A. Br J Pharmacol 144, 961-971.

[186] Kurapati KR, Atluri VS, Samikkannu T, Nair MP (2013) Ashwagandha (Withania somnifera) reverses $\beta$-amyloid142 induced toxicity in human neuronal cells: Implications in HIV-Associated Neurocognitive Disorders (HAND). PLoS One 8, e77624.

[187] Lee WH, Loo CY, Bebawy M, Luk F, Mason RS, Rohanizadeh R (2013) Curcumin and its derivatives: Their application in neuropharmacology and neuroscience in the 21st century. Curr Neuropharmacol 11, 338-378.

[188] Cole GM, Teter B, Frautschy SA (2007) Neuroprotective effects of curcumin. Adv Exp Med Biol 595, 197-212.

[189] Daneschvar HL, Aronson MD, Smetana GW (2015) Do statins prevent Alzheimer's disease? A narrative review. Euro J Intern Med 26, 666-669.

[190] Cramer C, Haan MN, Galea S, Langa KM, Kalbfleisch JD (2008) Use of statins and incidence of dementia and cognitive impairment without dementia in a cohort study. Neurology 71, 344-350.

[191] Sparks DL, Kryscio RJ, Sabbagh MN, Connor DJ, Sparks LM, Liebsack C (2008) Reduced risk of incident AD with elective statin use in a clinical trial cohort. Curr Alzheimer Res 5, 416-421.

[192] Haag MD, Hofman A, Koudstaal PJ, Stricker BH, Breteler MM (2009) Statins are associated with a reduced risk of Alzheimer disease regardless of lipophilicity. The Rotterdam Study. J Neurol Neurosurg Psychiatry 80, 13-17.

[193] Swiger KJ, Manalac RJ, Blumenthal RS, Blaha MJ, Martin SS (2013) Statins and cognition: A systematic review and meta-analysis of short- and long-term cognitive effects. Mayo Clin Proc 88, 1213-1221.

[194] McGuinness B, Craig D, Bullock R, Passmore P (2009) Statins for the prevention of dementia. Cochrane Database Syst Rev 2, CD003160.

[195] Lezoualc'h F, Sparapani M, Behl C (1998) N-acetylserotonin (normelatonin) and melatonin protect neurons against oxidative challenges and suppress the activity of the transcription factor NF-kappaB. J Pineal Res $\mathbf{2 4}, 168$ 178.

[196] Pappolla MA, Chyan YJ, Poeggeler B, Frangione B, Wilson G, Ghiso J, Reiter RJ (2000) An assessment of the antioxidant and antiamyloidogenic properties of melatonin: Implications for Alzheimer's disease. J Neural Transm (Vienna) 107, 203-231.
[197] Deng YQ, Xu GG, Duan P, Zhang Q, Wang JZ (2005) Effects of melatonin on wortmannin-induced tau hyperphosphorylation. Acta Pharmacol Sin 26, 519-526.

[198] Vgenopoulou I, Katsa ME, Tzavella F (2015) Melatonin levels in Alzheimer disease. Int J Car Sci 8, 499-506.

[199] Mirsadeghi S, Dinarvand R (2015) Can nanoparticles be beneficial for the early detection and treatment of Alzheimer disease. J Med Hypo Ideas 9, 86-87.

[200] Simmons-Stern NR, Budson AE, Ally BA (2010) Music as a memory enhancer in patients with Alzheimer's disease. Neuropsychologia 48, 3164-3167.

[201] Simmons-Stern NR, Deason RG, Brandler BJ, Frustace BS, O'Connor MK, Ally BA, Budson AE (2012) Music-based memory enhancement in Alzheimer's disease: Promise and limitations. Neuropsychologia 50, 3295-3303.

[202] Ueda T, Suzukamo Y, Sato M, Izumi S (2013) Effects of music therapy on behavioral and psychological symptoms of dementia: A systematic review and meta-analysis. Age Res Rev 12, 628-641.

[203] Rahman A, Salam F, Islam MA, Anwarullah AKM, Islam MR, Nurul M, Miah A, Saha UK, Ali Z (2012) Alzheimer's disease - an update. Bangladesh J Neurosci 28, 52-58.

[204] Ng M, Freeman MK, Fleming TD, Robinson M, DwyerLindgren L, Thomson B, Wollum A, Sanman E, Wulf S, Lopez AD, Murray CJ, Gakidou E (2014) Smoking prevalence and cigarette consumption in 187 countries, 1980-2012. JAMA 311, 183-192.

[205] WHO. Global adult tobacco survey (GATS): Bangladesh. World Health Organization 2009. http://www.who.int/ tobacco/surveillance/fact_sheet_of_gats_bangladesh_2009. pdf

[206] Global Tobacco Surveillance System. Global Adult Tobacco Survey - Bangladesh report 2009. Dhaka: World Health Organization, Country office for Bangladesh; 2009. http://www.searo.who.int/bangladesh/publications/gats_ 2009/en/

[207] Ng M, Fleming T, Robinson M, Thomson B, Graetz N, Margono C, Mullany EC, Biryukov S, Abbafati C, Abera SF, Abraham JP, Abu-Rmeileh NM, Achoki T, AlBuhairan FS, Alemu ZA, Alfonso R, Ali MK, Ali R, Guzman NA, Ammar W, Anwari P, Banerjee A, Barquera S, Basu S, Bennett DA, Bhutta Z, Blore J, Cabral N, Nonato IC, Chang JC, Chowdhury R, Courville KJ, Criqui MH, Cundiff DK, Dabhadkar KC, Dandona L, Davis A, Dayama A, Dharmaratne SD, Ding EL, Durrani AM, Esteghamati A, Farzadfar F, Fay DF, Feigin VL, Flaxman A, Forouzanfar MH, Goto A, Green MA, Gupta R, Hafezi-Nejad N, Hankey GJ, Harewood HC, Havmoeller R, Hay S, Hernandez L, Husseini A, Idrisov BT, Ikeda N, Islami F, Jahangir E, Jassal SK, Jee SH, Jeffreys M, Jonas JB, Kabagambe EK, Khalifa SE, Kengne AP, Khader YS, Khang YH, Kim D, Kimokoti RW, Kinge JM, Kokubo Y, Kosen S, Kwan G, Lai T, Leinsalu M, Li Y, Liang X, Liu S, Logroscino G, Lotufo PA, Lu Y, Ma J, Mainoo NK, Mensah GA, Merriman TR, Mokdad AH, Moschandreas J, Naghavi M, Naheed A, Nand D, Narayan KM, Nelson EL, Neuhouser ML, Nisar MI, Ohkubo T, Oti SO, Pedroza A, Prabhakaran D, Roy N, Sampson U, Seo H, Sepanlou SG, Shibuya K, Shiri R, Shiue I, Singh GM, Singh JA, Skirbekk V, Stapelberg NJ, Sturua L, Sykes BL, Tobias M, Tran BX, Trasande L, Toyoshima H, van de Vijver S, Vasankari TJ, Veerman JL, Velasquez-Melendez G, Vlassov VV, Vollset SE, Vos T, Wang C, Wang X, Weiderpass E, Werdecker A, Wright JL, Yang YC, Yatsuya H, Yoon J, Yoon SJ, 
Zhao Y, Zhou M, Zhu S, Lopez AD, Murray CJ, Gakidou E (2014) Global, regional, and national prevalence of overweight and obesity in children and adults during 1980-2013: A systematic analysis for the Global Burden of Disease Study 2013. Lancet 384, 766-781.

[208] Rahman S, Islam MT, Alam DS (2014) Obesity and overweight in Bangladeshi children and adolescents: A scoping review. BMC Public Health 14, 70.
[209] Imtiaz B, Tolppanen AM, Kivipelto M, Soininen H (2014) Future directions in Alzheimer's disease from risk factors to prevention. Biochem Pharmacol 88, 661-670.

[210] Bullock R (2004) Future directions in the treatment of Alzheimer's disease. Expert Opin Investig Drugs 13, 303-314. 